\title{
CLINICAL MANIFESTATIONS OF PERIPHERAL NERVOUS SYSTEM INVOLVEMENT IN HUMAN CHRONIC CHAGAS DISEASE
}

\author{
OSVALDO GENOVESE*, CARLOS BALLARIO**, RUBEN STORINO***, \\ ELSA SEGURA **, ROBERTO E.P. SICA*
}

\begin{abstract}
We conducted a clinical and electromyographical study in patients with Chagas' disease in the indeterminate or chronic stages of the illness. Altogether 841 patients were examined. Only 511 were admitted within the protocol; the remainder patients were rejected because they showed other causes able to damage the nervous system. Fifty two (10.17\%) out of the 511 patients showed signs and symptoms of peripheral nervous system involvement in the form of sensory impairment and diminished tendon jerks suggesting the presence of neuropathy. Forty five of them were submitted to a conventional electromyographical examination. Fifteen of them showed normal results, while the remainder 30 disclosed a reduced interference pattern, being most of the remaining motor unit potentials fragmented or poliphasic, reduced sensory and motor conduction velocities and diminished amplitude of the sensory action potential. The findings suggest that some chagasic patients in the indeterminate or chronic stages of the disease may develop a clinical mild sensory-motor peripheral neuropathy.
\end{abstract}

KEY WORDS: Chagas' disease, neuropathy, clinical assessment.

Manifestaciones clinicas de compromiso del sistema nervioso periferico en el estadio cronico de la enfermedad de Chagas

RESUMEN - El estudio presente fue diseñado con el objeto de pesquizar la existencia de manifestaciones clinicas en pacientes afectados por enfermedad de Chagas, en estadio indeterminado o cronico, que tuviesen, al menos, 2 reacciones serologicas positivas. En total fueron examinados 841 enfermos. De ellos solo 511 fueron admitidos en el protocolo; los restantes fueron rechazados por mostrar la presencia de otras causas que hubiesen podido dañar su sistema nervioso. Dentro de los 511 pacientes admitidos, $52(10.17 \%)$ evidenciaron alteraciones objetivas y subjetivas de la sensibilidad y disminucion de los reflejos osteotendinosos. Estos signos y sintomas, que sugieren la presencia de neuropatia, podian combinarse de diferente manera. Como complemento del examen clinico, se efectuo estudio electromiografico convencional en 45 de estos pacientes. En 15 los hallazgos fueron normales, en tanto que en los restantes 30 pudo demostrarse reduccion de la capacidad de reclutamiento voluntario de unidad motora, presencia de potenciales de unidad motora fragmentados o polifasicos, reduccion de la velocidad de conduccion motora y sensitiva y disminucion de la amplitud del potencial sensitivo. Los resultados obtenidos señalan que una proporcion de los pacientes en el estadio indeterminado o cronico de la infeccion pueden desarrollar una moderada neuropatia sensitivo-motora con expresion clinica.

PALABRAS-CHAVES: enfermedad de Chagas, neuropatia, evaluacion clinica.

Peripheral nervous system involvement in chronic Chagas disease has been found in humans $\mathrm{s}^{3,5,14-18}$ and in experimental animals ${ }^{7-13,21,22}$ by employing electrophysiological and anatomical techniques. However, clinical peripheral neurological manifestations have been seldom described in the literature ${ }^{1.2}$. Most of those papers refer to single or, at most, few cases without a systematic searching of this compromise in the infected population.

Division Neurologia, Hospital Ramos Mejia, Universidad de Buenos Aires, Buenos Aires (*), Hospital Centenario, Universidad de Rosario, Rosario, Santa $\mathrm{Fe}\left({ }^{* *}\right)$; Instituto para el Diagnostico y Tratamiento de la Enfermedad de Chagas Dr. Fatala Chaben, Buenos Aires (***). Aceite: 24-Janeiro-1996.

Dr. R.E.P. Sica - Division Neurologia, Hospital Ramos Mejia - Urquiza 609 - 1221 Buenos Aires - Argentina Fax 5419525658 . 
The aim of this paper is to present the results obtained in a large series of patients with chronic Chagas' disease, looking for clinical signs and/or symptoms of peripheral nervous system damage. Preliminary and partial results have been published elsewhere ${ }^{6}$.

\section{MATERIAL AND METHODS}

Eight hundred and forty one patients were examined during the last 3 years in the Chagas disease outpatient clinics at the Ramos Mejia and Centenario Hospitals at Buenos Aires and Rosario respectively. For avoiding inter-observer subjective variability the clinical examination in every patient was carried on only by 2 observers, O.G. at Buenos Aires and C.B. at Rosario.

The criteria for being included within the protocol were:

a. Both sexes with age below 60 years'?

b. Positivity of at least 2 out of 3 serological diagnostic tests for Chagas' disease.

c. Patients should have not received trypanosomicides drugs at any time previously.

d. Patients should have not been affected by any other disease able to damage the central or peripheral nervous systems at any time previously.

e. Patients should not be or have been in contact with toxics able to yield central or peripheral nervous systems involvement.

Three hundred and thirty (39\%) patients were discarded because the following reasons:

a. More than 60 years of age $(n: 20)$.

b. To show only one positive diagnostic serological test for Chagas' disease ( $n: 11$ ).

c. To have been treated with trypanosomicide drugs ( $\mathrm{n}: 18$ )

d. To have been afflicted by diseases able to damage the nervous system [leprosy ( $n: 2)$, arthritis ( $\mathrm{n}: 2$ ), diabetes $(n: 19)$, chronic renal failure ( $n: 2)$, tuberculosis treated with isoniazid ( $n: 8)$, severe depression on treatment $(n: 5)$, backpain or neckpain ( $n: 11)$, multiple trauma with peripheral nervous system involvement ( $n: 1)$, stroke $(n: 3)$, electrical shock (n:1), parkinsonism (n:1), cysticercosis (n:1), brucellosis (n:1), hypothyroidism (n:6), poliomyelitis ( $n: 2)$, neoplasms $(n: 2)$ and periodic paralysis $(n: 1)]$

e. To have been in contact with toxics able to damage the nervous system [more than $40 \mathrm{~g}$ of alcohol daily ( $n: 146)$, organophosphate poisonings (n:11), amiodarona (n:16), $\mathrm{Pb}(\mathrm{n}: 17), \mathrm{CO}(\mathrm{n}: 2)$, diphenylhydantoin (n:5), snake bite $(n: 1)$, steroids $(n: 3)$, oil derivatives $(n: 9)$ and cocaine $(n: 2)]$.

Two hundred and twenty eight (44.6\%) out of the remaining 511 patients were females and $283(55.4 \%)$ were males. Their mean age was $36.9+10.88$ years, ranging between 18 and 59 years.

Seventy nine percent of these patients lived in rural areas, the remaining $21 \%$ inhabited small towns.

Seventy seven percent of them had mud brick houses, while the other $23 \%$ owned regular brick built houses.

Only $10 \%$ of the patients were aware about having been bitten by the Triatoma, developing a focal inflammatory lesion at the site of the sting. This was considered a definitive sign of primary infection.

Twenty nine percent of them knew that some of his/her relatives were also infected, $62 \%$ did not, and 9\% knew that his/her relatives have been studied and proved not to be infected.

The areas where the patients came from and their percentages were as follows:

a. Provinces: Santiago del Estero (24\%), Chaco (15\%), Buenos Aires (10\%), Tucuman (6\%), Corrientes (5\%), Cordoba (5\%), Salta (3\%), Jujuy (3\%), Catamarca (3\%), Entre Rios (2\%), San Luis (2\%), La Rioja (2\%), Misiones (2\%), Santa Fe (2\%), Formosa (1\%), La Pampa (1\%), San Juan (1\%), Rio Negro $(0.5 \%)$, Mendoza $(0.5 \%)$.

b. Federal District (3\%).

c. Neighboring Countries: Bolivia (5\%), Paraguay (3\%), Uruguay $(0.5 \%)$, Chile $(0.5 \%)$.

Patients were submitted to a clinical neurological protocol mainly designed to demonstrate involvement of the peripheral nervous system, though a complete neurological examination was carried on, searching for any central nervous system damage.

Patients showing peripheral nervous system involvement were invited to pursue the investigation submitting them to a conventional electromyographical study. 


\section{RESULTS}

Fifty two (10.17\%) out of the 511 patients admitted within the protocol showed one or more clinical neurological manifestation pointing out peripheral nervous system damage.

Sensory abnormalities, as expressed by paresthesias, touch and pain hyposthesia and vibration sense impairment were the main sensory findings $(67.3 \%)$.

Diminished tendon jerks was often found in these patients $(80.76 \%)$.

By combining the symptoms and signs observed, patients could be grouped as follows:

A. Only sensory abnormalities, 10 patiens (19.23\%)

B. Only diminished tendon jerks, 17 patiens $(32.69 \%)$

C. Sensory abnormalities and diminished tendon jerks, 25 patients (48.07\%).

The clinical features of all patients showing involvement of the peripheral nervous system are summarized in Figure 1. The mean age of this group was $35.5 \pm 10.15$ years which did not differ significantly from the whole population age.

Sensory impairment, in the form of paresthesia and/on diminished sensation on pinprick and touch, was one of the most usual manifestation (67.3\% of the affected subjects). Its distribution was variable; it was more frequently found in the lower limbs (28.84\% of the affected subjects), though it could involve the four limbs (36.5\%) and seldom was confined to the upper limbs $(1.9 \%)$. Vibration sense impairment was present only in the lower limbs in 4 patients $(7.7 \%)$.

Tendon reflexes were diminished in $80.76 \%$ of the patients, either in isolation or combined with sensory impairment. The most affected were the patellar and achilles reflexes.

No overt weakness was noted in any patient.

Forty five ( $86.53 \%)$ out of these 52 patients accepted the electromyographical investigation. Fifteen of them (33.33\%) showed normal results, while $30(66.66 \%)$ disclosed some abnormal

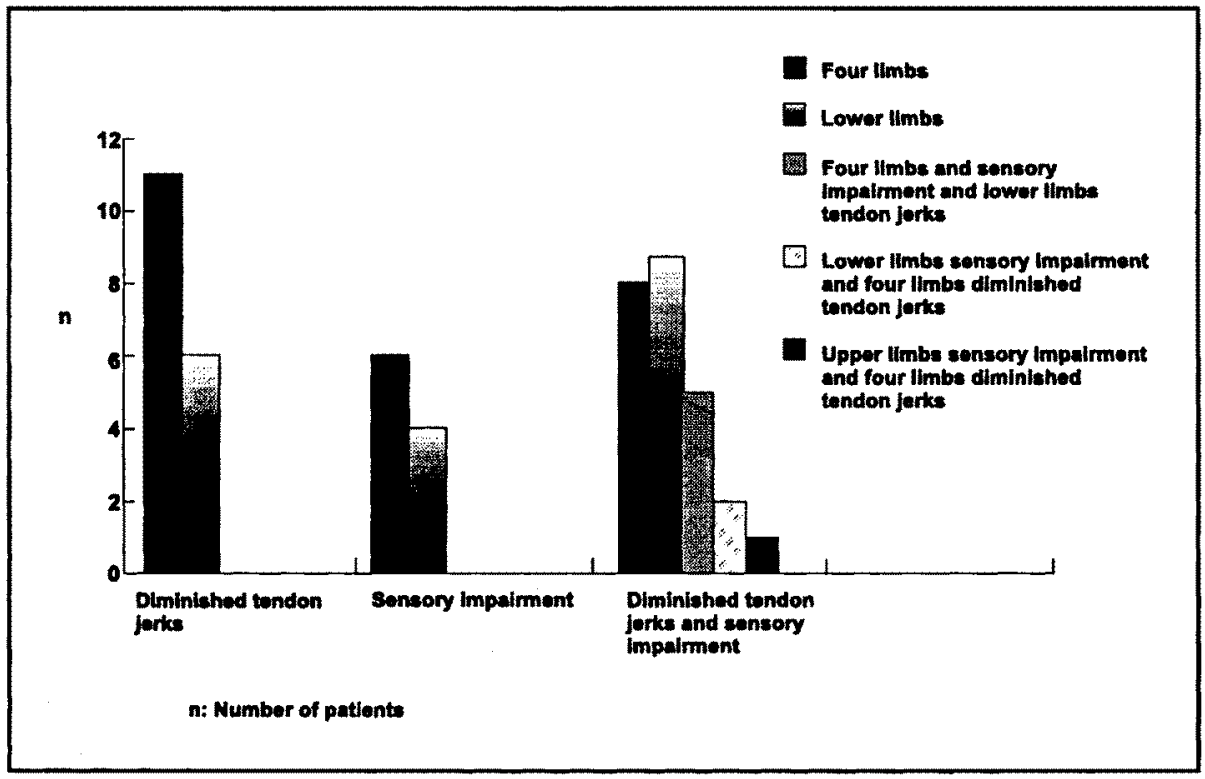




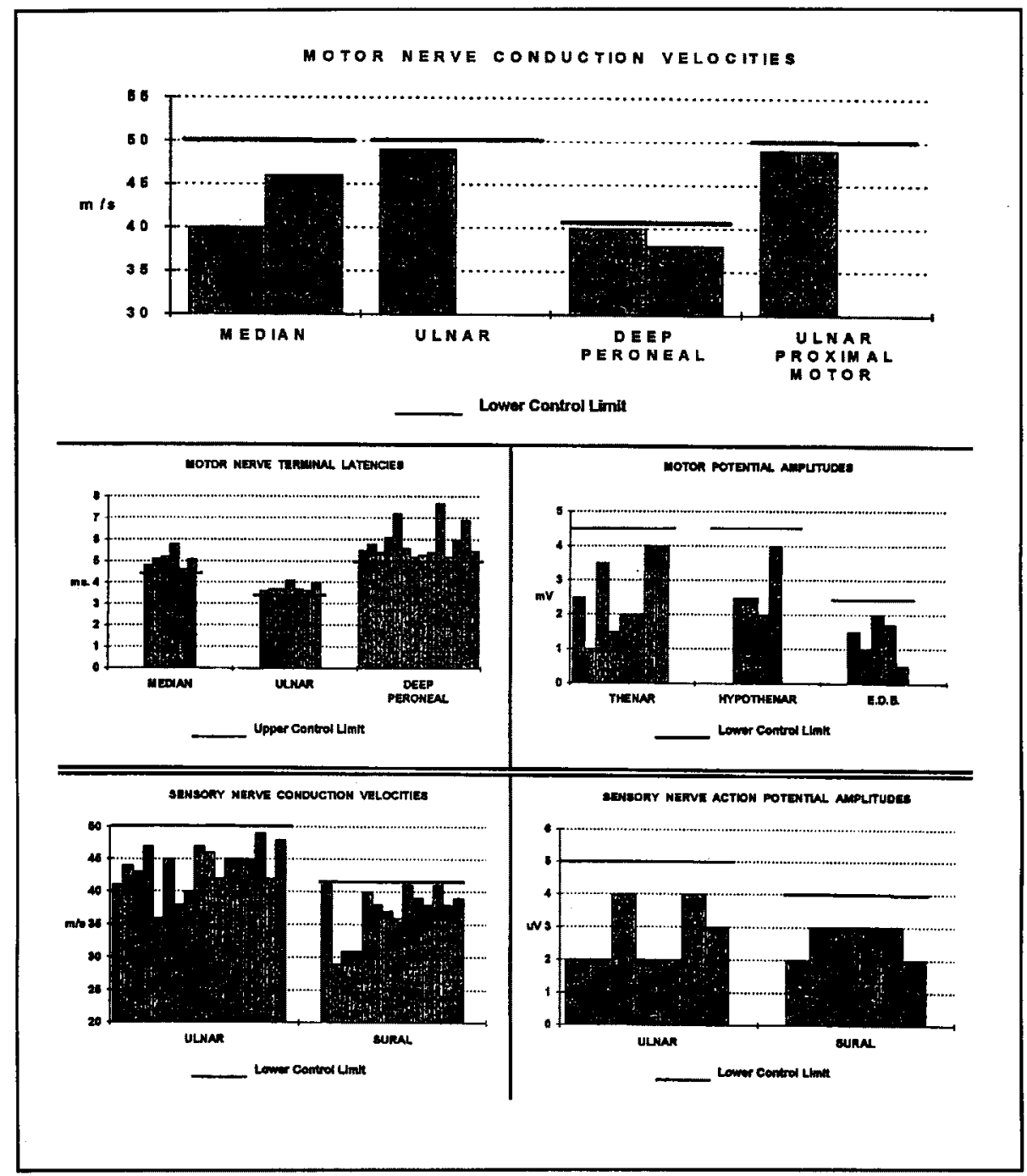

Fig 2. Nerve conduction studies. Each bar signals one subject. Data show only subjects with abnormal values.

electromyographical sign. According to these findings, these 30 patients could be grouped as follows: A. Only reduced interference pattern in proximal and distal muscles, being most of the remainder motor unit potentials poliphasic or fragmented, some of them with enlarged amplitude ( 5 patients). B. Abnormalities in motor nerve conduction studies were seen in 18 patients (Fig 2) in the form of reduced conduction velocity ( 1 patient), prolonged terminal latencies (13 patients) or the combination of both features ( 4 patients). Low muscle evoked potential amplitude was found in 10 patients; 15 out of these 18 patients had also sensory conduction abnormalities.

C. Reduced interference pattern plus impairment of nerve conduction studies, either motor or sensory, were found in 19 patients.

In every case, needle examination showed evidence of chronic denervation in patients showing either only reduced interference pattern ( 5 patients) or in those others who combined reduced interfe- 


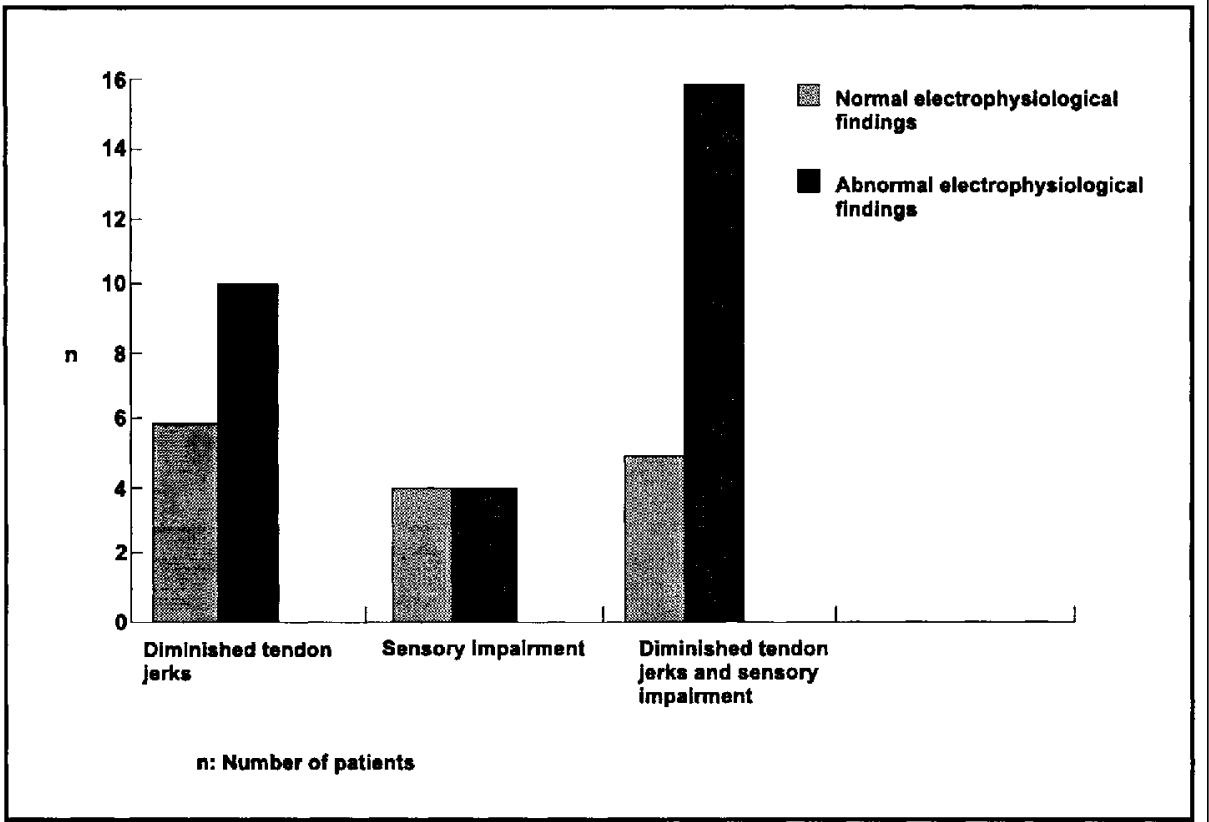

Fig 3. Relationship between clinical findings and electromyographical studies.

rence pattern and nerve conduction defects (19 patients); muscles mainly involved were the distal ones of the lower limbs. Figure 3 shows the relationship between the clinical and electrophysiological data. It can be seen that the electrophysiological abnormalities were present mainly in those patients who combined diminished tendon jerks and sensory impairment.

\section{DISCUSSION}

Sample validation - The number of patients in this study is about $0.022 \%$ of the total infected population within the Country ${ }^{4}$. They have been accepted into the protocol unselectively, constituting a random sample of those who have attended the Instituto para el Diagnostico y Tratamiento de la Enfermedad de Chagas in Buenos Aires or el Centro de Diagnostico para la Enfermedad de Chagas of the Hospital Centenario in Rosario between 1991 and 1994 . The geographical percentual origin of these patients is in line with the prevalence of the disease in the different areas of the Country where the patients came from ${ }^{20}$. Bias yield by other pathologies have been avoided as much as possible by excluding those patients with any suspicion of having been affected by diseases, infections, accidents or toxics which might have damaged their nervous system. Also the fact that the same observer, one in each clinic, always performed the clinical examination minimized subjectivity in recording data.

Methods justification - The methodology employed for investigating these patients is the usual in any neurological clinic; this is also true for the electromyographic searching. The reason for adopting these methods was that this attitude allows any neurologist to recognize the peripheral nervous system damage in chronic Chagas' disease patients in routine clinical and electromyographical examinations which may be done anywhere and in field studies. Both of them are very easy procedures and also very cheap, because the basic electromyographical machine needed should be provided just with a one channel recording system and a single pulse stimulator.

It is a well known feature that Chagas' disease may involve the peripheral nervous system in chronic infected patients ${ }^{3.16,18}$ or in the chronic infected mouse experimental model ${ }^{3,9}$. This notion 
was achieved employing electrophysiological and anatomical techniques for investigating humans and mice. However, even now it is not known which are the clinical implications of this compromise. The present survey has been conducted for searching such clinical involvement in a representative sample of patients with chronic Chagas' disease.

From the clinical viewpoint it was found that $10.17 \%$ of the patients chronically infected with T. cruzi had signs and/or symptoms of peripheral nervous system involvement. Most of the affected subjects showed a combination of sensory impairment and diminished tendon jerks. Both features suggest the presence of neuropathy, which mainly involve the lower limbs. This observation is in line with features previously disclosed in the experimental model, where it was found that the mice lower limbs and the spinal lumbar cord were the most affected structures ${ }^{7,12}$.

The paramount manifestations of this neuropathy were the sensory disturbances. It is worthy to note that weakness was not noted in these patients. The sensory impairment predominance also is in line with findings of previous studies where it was observed, electrophysiologically, overt compromise of sensory fibres ${ }^{16}$ and mild involvement of motor axons ${ }^{17}$. In the present investigation the figures obtained electrophysiologically showed a prominent damage of the sensory fibres.

The type of the neuropathy observed deserves some considerations. The slowness of conduction velocities in sensory and motor fibres suggest demyelination, though no signs of conduction block were found. However, the diminished amplitude of the sensory action potential and the muscle reduced voluntary interference pattern also signal axonal loss. Most probably both types of lesions are combined. These conclusions are also supported by earlier works where axonal loss, segmental and paranodal demyelination were described in the sural nerves of patients with this condition ${ }^{16}$ and in the sciatic nerve of mice experimentally infected?.

In the present investigation we have not found clinical evidences of spinal motoneurones damage. However, their involvement was suggested by the presence of some polyphasic enlarged amplitude motor unit potentials in patients with a electromyographical reduced voluntary interference pattern. This observation is not a new one, because it was described previously in humans ${ }^{3,18}$ and agrees with the findings of Molina et al. ${ }^{12}$ who showed reduced number of large motoneurones in the spinal anterior horn of mice chronically infected with the Tulahuen strain of the T. cruzi. A likely explanation for these apparently at variance clinical results is that the amount of motoneurones involved does not reached the levels needed to give overt clinical manifestations.

Taken together, the present findings signal that about $10 \%$ of the subjects chronically infected may develop a predominantly sensory neuropathy which is mild enough as not to preclude the patients for doing their current toils. However, a shortcoming of this study is that it constitutes a transversal analysis and gives no clues of the outcome of the affected subjects. From mice studies, it is known that the damage of the peripheral nervous system may progress along time'. Therefore, it is warranted to proceed this investigation further obtaining data on the follow-up of the symptomatic subjects.

\section{REFERENCES}

1. Chagas C. Les formes nerveuses d'un nouvelle trypanosomyase, T. Cruzi inocule par Tryatoma Megista. Nouv Iconogr Sapetriere 1913;26:1-10.

2. Collares-Moreira JV. A forma nervosa da molestia de Chagas. Thesis, Faculdade de Medicina de Rio de Janeiro. Rio de Janeiro, 1925.

3. De Faria CR, Melo Souza SE, Rassi A. Evidencias eletromiograficas de desnervacao motora em pacientes na fase cronica da doenca de Chagas. Rev Goiana Med 1977;23:125-130.

4. Esquivel M, Segura E. Estimacion del numero de infectados chagasicos en la Argentina (carta al Editor) Medicina 1994;54:91-92.

5. Garcia Erro M, Genovese O, Correale J, Sica REP. Neuromuscular transmission studies in human chronic Chagas' disease. Arq Neuropsiquiatr 1989;47:279-282.

6. Genovese O, Ballario C, Marelli E, Segura E, Riarte A, Sica REP. Compromiso clinico del sistema nervioso periferico en la enfermedad de Chagas cronica humana. Rev Neurol Arg 1992;17:79-82. 
7. Gonzalez Cappa SM, Sanz OP, Muiler LA, Molina HA, Fernandez J, Rimoldi MT, Sica REP. Peripheral nervous system damage in experimental chronic Chagas' disease. Am J Trop Med Hyg, 1987;36:41-45.

8. Koberle F, Alcantara F. Mecanismo de destruicao neuronal do sistema nervoso na molestia de Chagas. Hospital 1960;57:1057-1060.

9. Losavio A, Jones M, Sanz OP, Mirkin G, Gonzalez Cappa SM, Muchnik S, Sica REP. A sequential study of the peripheral nervous system involvement in experimental Chagas' disease. Am J Trop Med Hyg 1989;41:539-546.

10. Losavio A, Sica REP, Sanz OP, Mirkin G, Gonzalez Cappa SM, Muchnik S. Functional changes of the sciatic nerve in mice chronically infected with Trypanosoma cruzi. Medicina 1993;53:129-132.

11. Mirkin G, Jones M, Sanz OP, Rey RD, Sica REP, Gonzalez Cappa SM. Experimental Chagas' disease: electrophysiology and cell composition of neuromyopatic inflammatory lesions in mice infected with myotropic and pantropic strains of Trypanosoma cruzi. Clin Immunol Immunopathol 1994;73:69-79.

12. Molina HA, Cardoni R, Rimoldi MT. The neuromuscular pathology of experimental Chagas' disease. J Neurol Sci 1987;81:287-291.

13. Said G, Joskowits M, Barreira A, Eisen $H$. The neuromuscular pathology of experimental Chagas' disease. Ann Neurol, 1985;18:676-681.

14. Sanz OP, Ariustimuño G, Ratusnu AF, O'Neill E, Sica REP. An electrophysiological investigation of skeletal muscle in human chronic Chagas' disease. Arq Neuropsiquiatr 1978;36:319-326

15. Sanz OP, Ratusnu AF, Aristimuño G, O'Neill E, Sica REP. Despoblacion de neuronas motoras alfa en la enfermedad de Chagas cronica. Medicina, 1977;37:551.

16. Sica REP, Filipini D, Panizza M, Fumo T, Basso S, Lazzari J, Molina HA. Involvement of the peripheral sensory nervous system in human chronic Chagas' disease. Medicina, 1986;46:662-669.

17. Sica REP, Genovese $O$, Garcia Erro $M$. Peripheral motor nerve conduction studies in patients with chronic Chagas' disease. Arq Neuropsiquiatr 1991;49:405-408.

18. Sica REP, Sanz OP, Aristimuño G, Basso S, Fumo T, Pagano M, Taratuto A, Ratusnu AF, Colombi A. Muscle denervation in chronic Chagas' disease. Medicina 1979;39:579-588.

19. Sica REP, Sanz OP, Colombi A. The effects of aging upon the human soleus muscle: an electrophysiological study. Medicina, 1976;36:443-448.

20. Storino R, Barragan H. Epidemiologia. In Storino R, Milei J (eds). Enfermedad de Chagas. Buenos Aires: J. Mosby 1994.

21. Vichi FL. Molestia de Chagas experimental: parasitismo na cadeina ganglionar simpatica, medula espinal, ganglio raquideano, e musculatura estriada. Hospital 1963;64:131-138.

22. Villela E, Magarinhos Torres CB. Estudo histopatologico do sistema nervoso central en paralisia experimental determinada pelo Schizotripanum cruzi. Mem Inst Oswaldo Cruz 1926;19:175-180. 